\title{
Rapid Growth of the Ovarian Follicle in Relation to Age and Laying Performance in Japanese Quail
}

\author{
Yutaka Sonoda, Takayuki Sato and Kiyoshi Imai \\ College of Agriculture and Veterinary Medicine, Nihon University, Fujisawa, 252
}

\begin{abstract}
The rapid growth pattern of ovarian follicles in laying quail was examined during the period from 2 to 10 months of age by the use of three kinds of the fat soluble dye. The rapid growth period length was longest at 2 months of age and shortest at 4 months of age. The period then tended to lengthen slightly with age. A continuous increase in follicular volume at the time of ovulation was found as age progressed. The number of growing follicles in ovary was relatively small from 2 to 6 months of age, then the number increased at 8 months of age. The total amount of daily yolk deposition increased from 2 to 8 months of age.

To clarify relation between the follicular growth pattern and the laying performance, quail were classified into three types according to their laying patterns. In both of type A, exhibiting relatively short clutches, and type B, showing long clutches, the growth period was longest at 2 months of age. On the other hand, the number of growing follicles in ovary remained a constant level in type A while increased gradually in type B as age progressed. The birds of type $\mathrm{C}$ laid their eggs around the clock regardless of the lightdark cycle with relatively long clutches. The growth period in this type increased basically with age, but the number of growing follicles continued to decrease until 6 months of age. The follicular volume at ovulation and the total amount of daily yolk deposition tended to increase as age advanced in all the laying types. The follicular growth period and the follicular volume at ovulation in the quail of type B were less than those of type $\mathrm{A}$ at the all ages examined. However, the total amount of daily yolk deposition in type $\mathrm{B}$ was large comparing with type $\mathrm{A}$ and $\mathrm{C}$.
\end{abstract}

(Jpn. Poult. Sci., 33 : 170-177, 1996)

Key words : Japanese quail, follicular growth, aging, laying pattern

\section{Introduction}

It is well known that the ovary in poultry consists of several yellow growing follicles with different sizes and many small white follicles. One of the small white follicles starts the accumulation of yolk after the largest follicle is ovulated. Then the follicle increases its volume every day and finally reaches ovulation. This process is commonly called the follicular rapid growth phase.

Follicular growth pattern in the hen (Gallus gallus domesticus) has been studied by several investigators. Yellow growing follicles in the rapid grow th phase are arranged in a hierarchical order based on size, and their number remains relatively constant in the indivuduals. Although the rapid growth pattern of ovarian follicles has been evidenced to be closely related to age and clutch length in laying hens (ZAKARIA et al., $1983,1984)$, there are only a few studies on the follicular growth pattern in other species of birds.

In Japanese quail (Coturnix japonica), ovipositions are mainly concentrated within 
the period from the later half of lighting to a few hours after the onset of darkness and their oviposition patterns are classified into three types (Opel, 1966 ; Konishi, 1980 ; SONODA et al., 1985).

This study was conducted to determine the effect of aging on the rapid growth pattern of ovarian follicles in laying quail during the period from 2 to 10 months of age. In addition, the follicular growth in aging was compared when quail were classified into three types on the basis of their laying patterns.

\section{Materials amd Methods}

Japanese quail of WE strain were individually caged at 5 weeks of age. The birds were maintained under $14 \mathrm{hr}$ lighting $(05: 00$ to $19: 00)$ and $10 \mathrm{hr}$ darkness and had free access to food and water. Oviposition times of each quail were automatically recorded.

Three fat soluble dyes, Sudan Black B (B), Sudan Red B (R) and Sudan Red 7B (7R) (Merck), were used to determine follicular growth pattern in laying quail relating to age. A gelatin capsule (size 5) containing 2, 4 or $2 \mathrm{mg}$ of the respective dye was alternately administered into each quail every day at around 10:00 hr. The capsules were given for 4 weeks at 2, 4, 6, 8 and 10 months of age. The order of dye administration was R, B and 7R. Yolks were examined for 3 weeks from 8 days after administration of the first dye capsule. Eggs with dye rings in the yolk were hard boiled and the yolk was cut into half from the germinal disc through the center of the latebra. The number of dye rings formed in the yolk was counted and long and short diameters through the latebra of each dye ring were measured.

Eighteen to 24 quail with a higher egg production rate were selected from a group of 120 quail at 2, 4, 6, 8 and 10 months of age. Average egg production rates of the age groups were 91.0, 92.8, 91.5, 92.5 and $88.3 \%$, respectively. Analyses of follicular growth pattern were conducted by methods described previously in the laying hen (IMAI, 1983). For this purpose four variables were calculated in all the yolks examined : length of the follicular rapid growth period, follicle volume at the time of ovulation, the number of growing follicles in ovary and total amount of daily yolk deposition into the growing follicles. Since the individuals received the dye at exactly $24 \mathrm{hr}$ intervals, length of the follicular rapid growth period was represented by the number of color rings formed in the yolk. Follicle volume at the ovulation was indicated as the yolk volume in the oviposited egg. The number of growing follicles in the ovary was shown by the number of yolks having the same color ring in eggs from each bird for several consecutive days. Finally, total amount of daily yolk deposition into the growing follicles was judged by the summation of yolk volumes between two successive rings derived from the same dyes in consecutive eggs.

To investigate the follicular growth in relation to the laying pattern, quail were subdivided into the three groups based on their laying patterns according to the results by SonOda et al. (1985). Type A, consisting mainly of quail with short clutches, was basically equal to the typical oviposition pattern in laying hens. In type B observed commonly in the birds with long clutches, ovipositions occurred every day between 10 and $13 \mathrm{hr}$ after the onset of light with the intervals of about $24 \mathrm{hr}$. Type C 
quail laid their eggs around the clock regardless of the light-dark cycle. The follicular grow th pattern in each type was examined in 3 or more quail at each age. Average egg production rates in $2,4,6,8$ and 10 month-old quail of each ty pe were 81.8, 87.6, 84.3, 91.0 and $83.3 \%$ respectively in type $\mathrm{A}, 94.5,99.0,96.0,93.4$ and $93.2 \%$ respectively in type $\mathrm{B}$ and $91.9,90.3,91.9,93.4$ and $87.9 \%$ respectively in type $\mathrm{C}$.

Duncan's multiple range test was applied to determine significant differences across ages and among three types for each variable.

\section{Results and Discussion}

\section{Follicular Growth in Relation to Age :}

The rapid growth period of ovarian follicles in laying quail was longest at 2 months of age. The growth period shortened significantly at 4 and 6 months of age, then slightly lengthened up to 10 months of age. The follicular volume at ovulation showed the smallest value at 2 months of age. Afterwards, the volume increased steadily up to 10 months of age (Table 1).

IMAI (1983) and ZAKARIA et al. (1983) reported a tendency toward shortening of the follicular growth period from 5 to 11 months of age and then lengthening of the period during 14 to 23 months of age. LACASSAGNE (1960) has also found that the growth period and the follicular weight at ovulation in laying hens of 78 weeks of age resulted in higher values than those of 44 weeks of age. A tendency of the changing pattern of the rapid growth period relating to age in the laying quail found in the present study coincided principally with the findings in the laying hen.

In the chicken, it is commonly known that the follicular volume at the time of ovulation increases continuously with age (IMAI, 1983 ; ZAKARIA et al., 1983). The present study obviously showed a durable increase in the follicular volume with age in the quail. These results indicate that the both species have the same characteristic on the follicular volume at ovulation with the aging process.

A slight fluctuation was found on the number of growing follicles in ovary relating to age. On the other hand, the total amount of daily yolk deposition increased significantly from 2 to 8 months of age (Table 2). In laying hens, the number of growing follicles / ovary was large (7.6 follicles in average) and the total amount of daily yolk deposition was remarkably small $\left(9.2 \mathrm{~cm}^{3}\right.$ in average) shortly after the first egg was laid. Afterward, the number of growing follicles decreased and remained a constant level between 11 to 23 months of age. The total amount of daily yolk deposition increased up to 8 months of age and then remained relatively constant (IMAI, 1983 ; ZAKARIA et al., 1983). To the contrary, a small number of hierarchical follicles was found in the quail at the age around the first egg laying and no decrease was found afterwards.

The total amount of daily yolk deposition in the quail increased with age, differing from the profile of laying hens. The major yolk precursors, vitellogenin and triglyceride-rich lipoprotein, are synthesized in the liver and transported to the ovary by the circulation in the bird. Production of the yolk precursors was stimulated mainly by estradiol-17 $\beta$ (WISKOcIL et al., 1980). It is considered that an increased amount of the daily yolk deposition with age in the quail results from the following 2 factors; a 
Table 1. Length of the rapid growth period of ovarian follicles and follicular volume at ovulation in laying quail at different ages

\begin{tabular}{|c|c|c|c|c|c|}
\hline \multirow{2}{*}{$\begin{array}{c}\begin{array}{c}\text { Age } \\
\text { (month) }\end{array} \\
2\end{array}$} & \multirow{2}{*}{$\begin{array}{c}\begin{array}{c}\text { No. of yolks } \\
\text { examined }\end{array} \\
322\end{array}$} & \multicolumn{2}{|c|}{$\begin{array}{l}\text { Growth period length } \\
\text { (day) }\end{array}$} & \multicolumn{2}{|c|}{$\begin{array}{l}\text { Follicular volume } \\
\qquad\left(\mathrm{mm}^{3}\right)\end{array}$} \\
\hline & & $5.04 \pm 0.05^{*}$ & $\mathrm{a}$ & $2786 \pm 21$ & $\mathrm{a}$ \\
\hline 4 & 338 & $4.83 \pm 0.04$ & $\mathrm{~b}$ & $2922 \pm 20$ & $\mathrm{~b}$ \\
\hline 6 & 286 & $4.84 \pm 0.04$ & $\mathrm{~b}$ & $3000 \pm 21$ & $\mathrm{c}$ \\
\hline 8 & 311 & $4.93 \pm 0.04$ & $a b$ & $3104 \pm 19$ & $\mathrm{~d}$ \\
\hline 10 & 222 & $4.94 \pm 0.05$ & $a b$ & $3143 \pm 29$ & $\mathrm{~d}$ \\
\hline
\end{tabular}

a, b, c, d : Means with the same letter within a column were not significantly different.

$*$ : Mean \pm S.E.M.

Table 2. The number of growing follicles in ovary and total amount of daily yolk deposition in laying quail at different ages

\begin{tabular}{|c|c|c|c|c|c|}
\hline \multirow{2}{*}{$\frac{\begin{array}{c}\text { Age } \\
\text { (month) }\end{array}}{2}$} & \multirow{2}{*}{$\begin{array}{c}\begin{array}{c}\text { No. of yolks } \\
\text { examined }\end{array} \\
17\end{array}$} & \multicolumn{2}{|c|}{$\begin{array}{l}\text { No. of growing } \\
\text { follicles/ovary }\end{array}$} & \multicolumn{2}{|c|}{$\begin{array}{l}\text { Total amount of daily } \\
\text { yolk deposition }\left(\mathrm{mm}^{3}\right)\end{array}$} \\
\hline & & $4.35 \pm 0.05^{*}$ & $\mathrm{a}$ & $2341 \pm 30$ & $\mathrm{a}$ \\
\hline 4 & 17 & $4.37 \pm 0.03$ & $\mathrm{a}$ & $2496 \pm 30$ & $\mathrm{~b}$ \\
\hline 6 & 16 & $4.35 \pm 0.04$ & $\mathrm{a}$ & $2604 \pm 33$ & $c$ \\
\hline 8 & 15 & $4.55 \pm 0.04$ & $\mathrm{~b}$ & $2727 \pm 33$ & $\mathrm{~d}$ \\
\hline 10 & 15 & $4.42 \pm 0.05$ & $\mathrm{a}$ & $2709 \pm 34$ & $\mathrm{~d}$ \\
\hline
\end{tabular}

a, b, c, d : Means with the same letter within a column were not significantly different.

* : Mean \pm S.E.M.

gradually highered ability of the liver to produce the yolk precursor materials in response to a certain amount of estrogen, and/or a gradually increased secretion of estrogen by growing follicles. Consequently, a gradually increased amount of the yolk precursor materials delivered to each growing follicle seems to be reflected to an increase of the follicle volume at ovulation.

\section{Follicular Growth in Relation to Laying Pattern :}

The follicular growth period was longest at 2 months of age and shortened at 4 months of age in quail exhibiting type A and B. In type A, the growth period lengthened slightly at 6 months of age and then shortened again as age progressed. The growth period in type B remained relatively short until 10 months of age. To the contrary, a profile of the growth period with age in type $\mathrm{C}$ differed from the above 2 types; it showed an increase in aging, only excepting 6 months of age, so that the longest period was found at 10 months of age (Fig. 1). The growth period in type B was significantly shorter than that in type A for all the ages studied (Fig. 2). Follicular volume at the time of ovulation was smallest at 2 months of age and then increased substantially as age progressed in all types (Fig. 1). Type B showed the smallest follicular volume through the ages examined, differing significantly from type A all ages excepting only at 8 months of age (Fig. 2).

Our findings on the follicular growth period and the volume in quail agree with those found in laying hens (IMAI, 1983 ; ZAKARIA et al., 1984). They found that the follicular growth period tended to shorten and the ovulatory follicle volume had a 

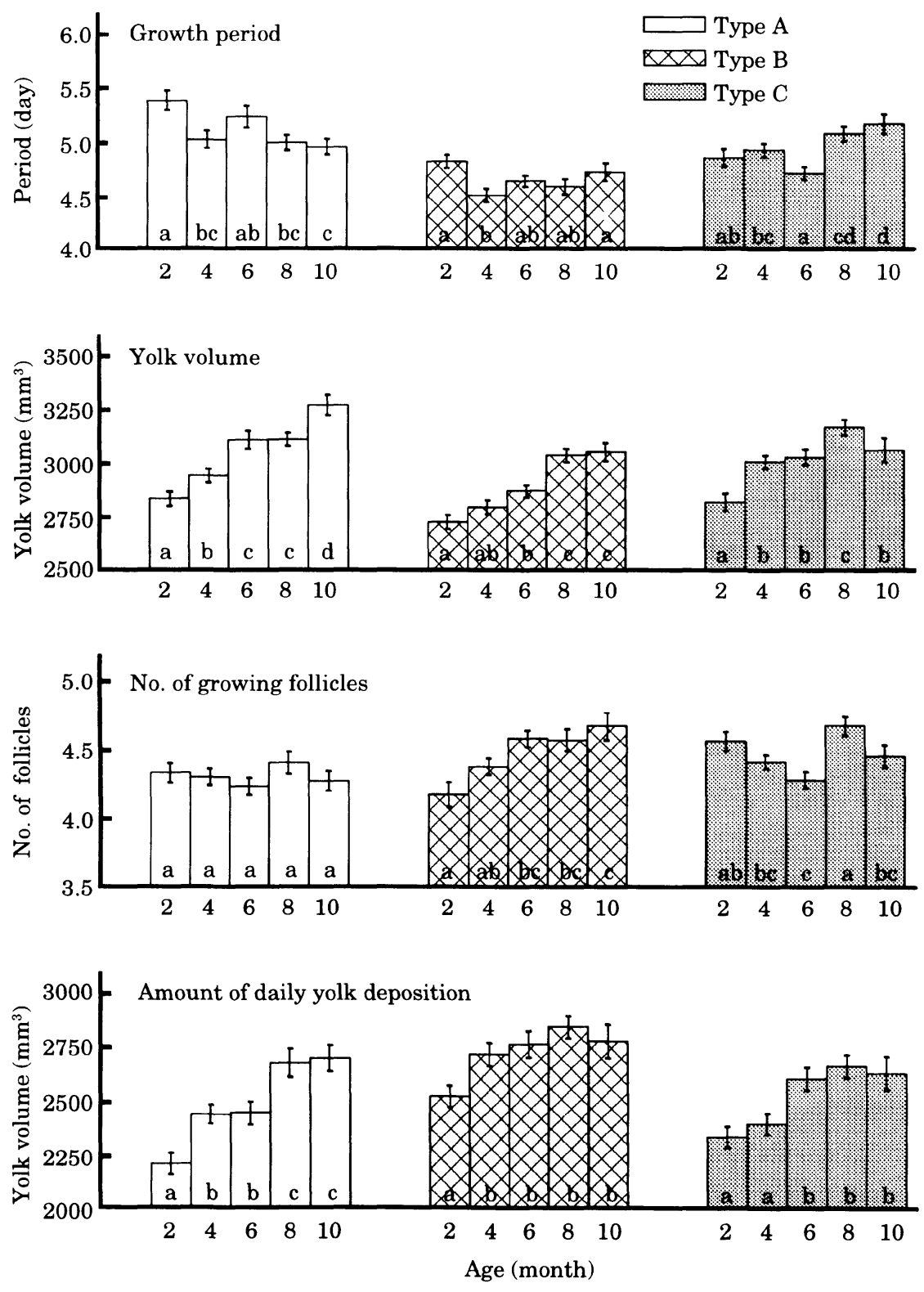

Fig. 1. Changes in the follicular growth pattern as age advances in laying quail showing 3 ovipository types.

a, b, c, d : means with the same letter for each type were not significantly different.

tendency to be small as the clutch length increased. In the present study, quail exhibiting type A laid their eggs with relatively short clutches, while longer clutches were commonly observed in the quail showing type B.

The number of ovarian growing follicles in type A remained approximately constant throughout the ages examined. The ovary of type B quail possessed the 

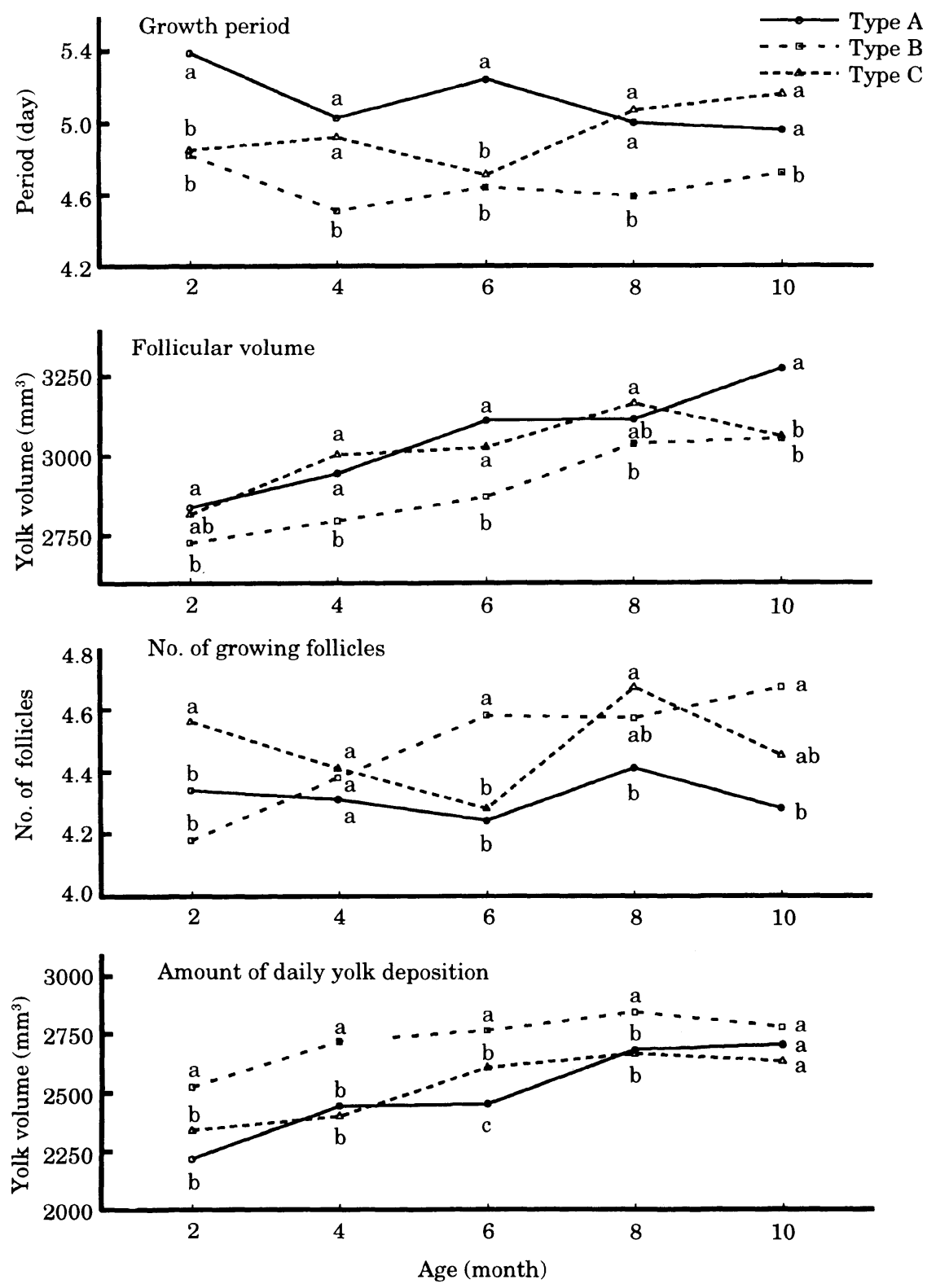

Fig. 2. Comparison of the follicular growth pattern among 3 ovipository types in laying quail with advancement of age.

a, b, c: means with the same letter for each age were not significantly different.

smallest number of follicles at 2 months of age, then the number increased. The number of follicles in type $\mathrm{C}$ decreased significantly from 2 to 6 months of age, but increased significantly at 8 months of age. There was a significant difference on the number of growing follicles between type A and B during 6 to 10 months of age. The total amount of daily yolk deposition generally tended to increase as age advanced in 
all types. Type B quail provided more amounts of yolk than the other types, differing significantly from type A during 2 to 8 months of age.

IMAI (1983) and ZAKARIA et al. (1984) reported that the number of rapidly growing follicles / ovary in laying hens with short clutches was significantly smaller than that of hens with long clutches. LACASSAGNE (1957) also found a significant difference between short and long clutch layers on the number of growing follicles in ovary. Furthermore, GILBERT (1972) reported an increase in the number of growing follicles / ovary as the clutch lengthened. Williams and SHARP (1978) observed that the number of rapidly growing follicles in the ovary of good and poor layers at 82 weeks of age was 6.0 and 5.0, respectively. Our results coincided well with the findings in laying hens.

In our study, type A quail showed the longest follicular growth period at young age and then revealed shortening of the period with a relatively constant number of growing follicles in aging. In contrast, type B had short and relatively constant growth period and a gradual increase in the number of growing follicles over the ages examined. Furthermore, total amount of daily yolk deposition in type B reached a constant level at younger age ( 4 month-old) in comparison with the other types. It is therefore considered that in ty pe B quail, the ability to induce a higher egg production based on a harmonious endocrine relationship is established at an earlier age.

\section{Acknowledgment}

We are indebted to Mr. K. Misono for his technical help.

\section{References}

Gilbert, A.B. (1972) The activity of the ovary in relation to egg production. In 'Egg Formation and Production (Freeman, B.M. and P.E. Lake, eds.)', pp.3-21. British Poultry Science Limited, Edinburgh.

IMAI, K. (1983) Characteristics of rapid growth of the ovarian follicles in the chiken. In 'Avian Endocrinology (MıкамI, S. et al., eds.)', pp. 117-124. Japan Scientific Society Press, Tokyo, and Springer-Verlag, Berlin, Heidelberg and New York.

Konishi, T. (1980) Circadian rhythm of ovipositional time in Japanese quail. In 'Biological Rhythms in Birds (Tanabe, Y.et al., eds.)', pp. 79-90. Japan Scientific Society Press, Tokyo, and Springer -Verlag, Berlin, Heidelberg and New York.

LACASSAGne, L. (1957) Dynamique de l'ovogenèse. Contribution a l'étude de la phase de grand accroissement des follicules chez la poule domestique. Annales de Zootechnie, $2: 85-93$.

LACASSAGNE, L. (1960) Étude comparée des réserves vitellines et de la durée de la phase de grand accroissement de lóvocyte chez la poule domestique. Influence de láge de l'animal et de la longueur de la série. Annales de Zootechnie, 9 : 85-96.

OpeL, H. (1966) The timing of oviposition and ovulation in the quail (Coturnix coturnix japonica). 7 : 29-38.

SONODA, Y., K. IBARAKI and K. IMAI (1985) Clutch pattern and ovipository cycles in laying WE quail. Japanese Poultry Science, $22: 297-303$. (in Japanese)

WiLliams, J.B. and P.J. ShaRP (1978) Ovarian morphology and rates of ovarian follicular development in laying broiler breeders and commercial egg-producing hens. British Poultry Science, $19: 387-395$.

Wiskocil, R., P. BENSKy, W. Dower and R.G. DeLley (1980) Coordinate regulation of two estrogendependent genes in avian liver. Proceedings of the National Academy of Science of the USA, $77: 4474-4478$.

ZAKARIA, A.H., T. MIYAKI and K. IMAI (1983) The effect of aging on the ovarian follicular growth in 
laying hens. Poultry Science, 62 : 670-674.

ZAKARIA, A.H., T. MIYAKI and K. IMAI (1984) The relationships of clutch length and egg position on the ovarian follicular growth in laying hens. Poultry Science, $63: 1250-1254$.

\title{
日本ウズラにおける卵胞の急速成長に関する年齢および 産卵型の影響
}

\author{
園田 豊・佐藤隆之・今井 清 \\ 日本大学農獣医学部 藤沢 $\mathbf{T} 252$
}

日本ウズラの卵巣卵胞の急速成長パターンに及ぼす年 齢の影響について検討し，さらに産卵パターンによる卵 胞成長型の比較を行った。2 から10 か月齢の産卵ウズラ に脂溶性色素を経口投与し，色素輪が形成された卵黄を 用いて卵胞の急速成長に関する 4 形質 (卵胞の急速成長 期間, 排卵時の卵胞体積, 卵巣内の成長卵胞数, 1 日当た り卵黄総蓄積量）を求めた。

産卵ウズラにおける卵胞の急速成長期間は 2 か月齢で 最も長く, 4 か月粭で最も短くなった。その後, 加齢に伴 いわずかに伸長する傾向を示した。排卵時の卵胞体積の 連続的な増加が加龄に伴って認められた。1日当たり卵 黄総蓄積量も 8 か月齢まで増加し続けた。一方, 卵巣内
の成長卵胞数は 2 から 6 か月齢の期間で比較的一定で あったが，8か月齢で増加した。

長いクラッチを示すタイプ B の産卵ウズラにおいて, 卵胞の急速成長期間は実験期間を通じて短縮する傾向を 示したが，排卵時の卵胞体積と 1 日当たり卵黄総蓄積量 は他の産卵タイプに比べて高かった。また, 卵巣内の成 長卵胞数は加齢に伴い增加する傾向を示したが，他の夕 イプではこの傾向がみられなかった。

(家禽会誌, $33: 170-177,1996$ ) キーワード：日本ウズラ, 卵胞成長, 加龄, 産卵パター 